\title{
Characterization of white-fleshed peach cultivars grown in the 'Zona da Mata' area of Minas Gerais State, Brazil
}

\author{
Danielle Fabíola Pereira da Silva*, Rosana Gonçalves Pires Matias, José Osmar da Costa e Silva,
} Alejandro Hurtado Salazar, Claudio Horst Bruckner

Federal University of Viçosa, Viçosa, MG, Brazil

*Corresponding author, e-mail: danieele@ufv.br

\begin{abstract}
There are few information on the physical and chemical characteristics of peach fruit in subtropical climate regions and the majority of the studies were developed in the southern region of Brazil. In this study, physical and chemical characteristics of 12 white-fleshed peach cultivars (Cristal, Cristal Tacoari, Colibri, Delicioso Precoce, Jóia 1, Jóia 2, Jóia 4, Marli, Okinawa, Pérola de Itaquera, Premier and Tropical) were evaluated. The cultivars were planted in the experimental orchard of the Federal University of Viçosa (UFV), Viçosa - MG, Brazil. The experiment was conducted during the 2011 harvest season, in a completely randomized design with 12 treatments (cultivars), three replications and 10 fruits per plot. The cultivars Delicioso Precoce and Marli showed, in general, higher mass and fruit diameter. Fruits of cultivars Jóia 2 and Tropical presented higher firmness. Cultivar Tropical stood out with better balance between acidity and soluble solids and higher vitamin $C$ and carotenoids contents.
\end{abstract}

Keywords: Adaptation, Prunus persica, fruit quality

\section{Caracterização de pêssegos de polpa branca cultivados na região da Zona da Mata de Minas Gerais}

\section{Resumo}

Existem poucas informações sobre as características físicas e químicas de frutos de pessegueiro em regiões de clima subtropical, sendo a maioria dos trabalhos desenvolvidos na região Sul do Brasil. Desta forma, este trabalho objetivou avaliar características físicas e químicas de frutos de 12 cultivares de pessegueiro de polpa branca, a saber: Cristal, Cristal Tacoari, Colibri, Delicioso Precoce, Jóia 1, Jóia 2, Jóia 4, Marli, Okinawa, Pérola de Itaquera, Premier, Tropical. Elas foram introduzidas no pomar experimental da Universidade Federal de Viçosa (UFV), Viçosa-MG. O experimento foi conduzido durante a safra 2011 , em delineamento inteiramente casualisado, com 12 tratamentos (cultivares), três repetições e 10 frutos por parcela. As cultivares Delicioso Precoce e Marli apresentaram, no geral, maior massa e diâmetros de frutos. Os frutos das cultivares Jóia 2 e Tropical apresentaram maior firmeza de polpa. Tropical se destacou por apresentar melhor balanço entre sólidos solúveis e acidez e maiores teores de vitamina $\mathrm{C}$ e de carotenoides.

Palavras-chave: Adaptação, Prunus persica, qualidade de fruto 
The peach (Prunus persica (L.) Batsch) is one of the most cultivated fruit in the world. In Brazil, the temperate fruit production has been expanding in area and in productivity, due to the large market potential (Leonel et al., 2011). Few fruit species have fast adaptation to different climatic conditions (WAGNER JR et al., 2009). Peach is attractive due to its fruit aroma and nice color, being consumed mainly 'in natura', but also industrialized in different product forms, such as peaches in syrup, jams, juices etc.

Due to its excellent organoleptic quality, the peach is very appreciated in Brazil, as evidenced by the continuous increase of the fresh fruit consumption or processed into various products. Brazil imported in 2014 about 10,636 tons of peaches for fresh consumption (MDIC, 2015). It is observed a great market potential, since the internal production has not yet reached sufficient volume to meet domestic demand.

The culture of peach presents considerable importance worldwide. World production of peaches and nectarines in 2013 stood at around 21.6 million tons (FAO, 2015). In the same year, China, the world's largest producer, produced 11.92 million of tons and Brazil produced 217,706 tons. The Rio Grande do Sul State is the first national producer with 136,841 tons, followed by the state of São Paulo with a production of 26,849 tons (IBGE, 2015). In Minas Gerais, the crop is in development, concentrating its production mainly in the southern area of the state, due to the desirable soil and climatic characteristics of this region (Souza et al., 2009). According to IBGE (2015), the production of Minas Gerais State in 2013 was 20,139 tons, the fourth largest producer, however, with the highest productivity (22.55 tha-1).

According to Alexander et al. (2014), differences in fruit composition may be mainly related to planting location, climatic conditions, cultivar and maturity stage. There is little information on the physical and chemical characteristics of peach fruits produced in the subtropical region, although these are important for the guidance of growers regarding the decision about which cultivars should be chosen for planting. This study aimed to evaluate the physical and chemical characteristics of
12 white-fleshed peach cultivars in a region of subtropical climate.

The study was conducted during the 2011 harvest season, with 12 white-fleshed peach cultivars (Cristal, Cristal Tacoari, Colibri, Delicioso Precoce, Jóia 1, Jóia 2, Jóia 4, Marli, Okinawa, Pérola de Itaquera, Premier and Tropical) grown in the experimental orchard of the Federal University of Viçosa (UFV), Viçosa - MG, Brazil (20 $45^{\prime} \mathrm{S}$ and $42^{\circ} 51^{\prime} \mathrm{O} ; 649 \mathrm{~m}$ of altitude). The experiment was conducted in a soil classified as oxisol and the rootstock used for all cultivars was 'Okinawa' in a $4 \times 3 \mathrm{~m}$ spacing with the plant density of 833 plants per ha in open pots.

Fruits were picked when the background color changed from green to cream-white and evaluated for chemical and physical characteristics described as follows. Fruit mass (FM), in grams (g), was determined using a digital scale accurate to $0.1 \mathrm{~g}$. Longitudinal (LD) and transverse (TD) diameters, in $\mathrm{mm}$, were measured using a Mitutoyo DL-10 digital caliper. Flesh firmness (FIRM), in Newton (N), was measured on the equatorial region of one of the faces of each fruit after skin removal, using a digital Effegi penetrometer (TF-011) with an 8-mm diameter tip. Soluble solids content (SS) in ${ }^{\circ}$ Brix of the juice manually squeezed from one equatorial side of each fruit was determined using an ATAGO digital refractometer (Palette PR-101). Titratable acidity (TA) was obtained by titrating $5 \mathrm{~g}$ of flesh and 95 $\mathrm{ml}$ of distilled water with a $\mathrm{NaOH}$ solution, with results expressed as percentage of malic acid. The ratio soluble solids and titratable acidity (SS/TA) was calculated. The ascorbic acid content in the flesh (Vit C) was determined by the titration with Tillman's reagent [2,6 dichlorophenolindophenol (sodium salt) $0.1 \%$ ] and results expressed in $\mathrm{mg}$ of ascorbic acid per $100 \mathrm{~g}$ of flesh. The total carotenoids (TC) were obtained by the equations of Lichtenthaler (1987), in $\mu \mathrm{g} \cdot \mathrm{mL}^{-1}$ of extract, withspectrophotometer readings at 470, 646.8 and $663.2 \square \mathrm{m}$. The results were multiplied by 25 and divided by the mass of pulp and expressed in $\mathrm{mg} / \mathrm{l00g}$ flesh.

The experiment was arranged in a completely randomized design with 12 treatments (cultivars), three replications and ten fruits per plot. Three plants were used for each 
cultivar and ten fruits were harvest from each plant, totaling 30 fruits per cultivar. Data were submitted to variance analysis and means were compared by the Scott-Knott's test at $5 \%$ of probability. Analyses were performed using the GENES software (Cruz, 2006; version 2007).

Fruit mass varied significantly from 40.99 $\mathrm{g}$ (Tropical) to $99.67 \mathrm{~g}$ (Delicioso Precoce) (Table
1). Ramos \& Leonel (2008) evaluated peach and nectarine cultivars in Botucatu - SP and reported fruit mass values ranging from 68.64 to 141.35 g. They observed that fruits of cultivar Marli had an average mass of $75.5 \mathrm{~g}$, which was much lower than that obtained in this study (94.97 $\mathrm{g}$ ). According to Toralles et al. (2008), the fruit mass has influence on yield and processing cost.

Table 1. Fruit mass (FM), longitudinal diameter (LD), transverse diameter (TD) and firmness (FIRM) of fruits of 12 whitefleshed peach cultivars harvested in the region of Zona da Mata.

\begin{tabular}{lllll}
\hline \multicolumn{1}{c}{ Cultivars } & \multicolumn{1}{c}{ FM } & LD & TD & FIRM \\
\hline Cristal & $62.97 \mathrm{~b}$ & $48.79 \mathrm{c}$ & $47.71 \mathrm{c}$ & $71.32 \mathrm{~b}$ \\
Cristal Tacoari & $69.01 \mathrm{~b}$ & $52.51 \mathrm{~b}$ & $47.30 \mathrm{c}$ & $59.98 \mathrm{c}$ \\
Colibri & $50.36 \mathrm{c}$ & $45.45 \mathrm{~d}$ & $44.25 \mathrm{~d}$ & $71.82 \mathrm{~b}$ \\
Delicioso Precoce & $99.67 \mathrm{a}$ & $59.36 \mathrm{a}$ & $55.26 \mathrm{a}$ & $41.55 \mathrm{~d}$ \\
Jóia 1 & $82.23 \mathrm{~b}$ & $55.39 \mathrm{~b}$ & $51.48 \mathrm{~b}$ & $44.09 \mathrm{~d}$ \\
Jóia 2 & $68.49 \mathrm{~b}$ & $53.00 \mathrm{~b}$ & $46.66 \mathrm{C}$ & $86.58 \mathrm{a}$ \\
Jóia 4 & $72.41 \mathrm{~b}$ & $53.17 \mathrm{~b}$ & $50.16 \mathrm{~b}$ & $35.70 \mathrm{~d}$ \\
Marli & $94.97 \mathrm{a}$ & $61.90 \mathrm{a}$ & $54.74 \mathrm{a}$ & $46.42 \mathrm{~d}$ \\
Okinawa & $76.05 \mathrm{~b}$ & $61.15 \mathrm{a}$ & $47.37 \mathrm{C}$ & $48.02 \mathrm{~d}$ \\
Pérola de Itaquera & $67.44 \mathrm{~b}$ & $50.90 \mathrm{C}$ & $48.86 \mathrm{C}$ & $51.80 \mathrm{c}$ \\
Premier & $44.70 \mathrm{C}$ & $44.83 \mathrm{~d}$ & $40.97 \mathrm{e}$ & $73.31 \mathrm{~b}$ \\
Tropical & $40.99 \mathrm{c}$ & $40.41 \mathrm{~d}$ & $40.76 \mathrm{e}$ & $78.98 \mathrm{a}$ \\
\hline Means followed by the same letter in the columns are not significantly different at 5\% of probability by the Scott-Knott's test. FM (g); LD and TD (mm); FRM (N).
\end{tabular}

Fruits of $\mathrm{cV}$. Marli showed the highest mean for longitudinal diameter (LD), with 61.90 $\mathrm{mm}$, but did not differed significantly from Delicioso Precoce and Okinawa, with 59.36 and $61.15 \mathrm{~mm}$, respectively, whereas cv. Tropical produced fruits with the lowest LD, with 48.56 $\mathrm{mm}$. For the transversal diameter, the variation was slightly lower, with the highest diameter for Delicioso Precoce $(55.26 \mathrm{~mm}$ ) and the lowest for Tropical (40.76 mm) (Table 1). Albuquerque et al. (2000) evaluated peach and nectarine cultivars in Araponga - MG, Brazil and reported average diameters of 40.27, 40.11, 51.73, 41.46, 44.62 and $46.77 \mathrm{~mm}$ for the cultivars Cristal, Colibri, Marli, Okinawa, Premier and Tropical, respectively, which, except for Premier and Tropical, were lower than those found in this study.

Fruits of cultivars. Jóia 2 and Tropical had the highest means for firmness, indicating postharvest potential for this characteristic, since flesh firmness is related to resistance to transport and shelf life (Wagner Jr. et al., 201 1. According to Leite et al. (2010) and Montevecchi et al. (2012), it is essential to evaluate fruit quality in order to adopt measures for improvement and handling practices to meet marketing standards.

The highest content of soluble solids (SS) was observed in fruits of cultivar. Cristal, with $12.66^{\circ}$ Brix (Table 2). Similarly, the cultivars Cristal, Tacoari, Colibri and Delicioso Precoce were not significantly different from Cristal. Ramos \& Leonel (2008) found $16.3^{\circ}$ Brix for Cv. Marli, higher values when compared to the values found for this cultivar in the present study. Chitarra \& Chitarra (2005) pointed out that, in general, the soluble solids content varies with species, cultivars, maturity stages and climate.

The titratable acidity varied considerably, with cv. Jóia 4 (0.33\%) having the lowest content and cultivars Cristal, Tacoari and Okinawa with the highest contents (0.99). Silva et al. (2013) reported acidity levels ranging from 0.20 to $0.76 \%$ in fruits of five $\mathrm{F} 2$ populations containing between 9 and 61 plants in Araponga - MG.

It is possible to observe a wide variation for the obtained ratio of soluble solids/titratable 
acidity (SS/TA), from 11.23 to 30.60, which, according to Albuquerque et al. (2000), is favorable to selection, enabling the correct choice of cultivars that could be used depending on location and consumer preference.

Vitamin C contents ranged from $9.08 \mathrm{mg}$ $100 \mathrm{~g}^{-1}$ in the $\mathrm{cv}$. Pérola de Itaquera to $19.24 \mathrm{mg}$ $100 \mathrm{~g}^{-1}$, in the cv. Tropical (Table 3). Segantini et al. (2012), characterizing peach flesh produced in San Manuel/SP, reported vitamin C contents of

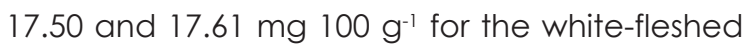
cultivars Chiripá and Marli, respectively. In the present study, cv. Marli showed lower vitamin C content, with $10.12 \mathrm{mg} 100 \mathrm{~g}^{-1}$. Segantini et al. (2012) discussed that vitamin $C$ levels in fruits, besides varying among cultivars, may also vary depending on other factors such as cultural practices and different cultivation sites.

Table 2. Soluble solids (SS), titratable acidity (TA), ratio between SS and TA (SS/TA), ascorbic acid (Vit C) and total carotenoids (TC) of fruits of 12 white-fleshed peach cultivars harvested in the region of Zona da Mata.

\begin{tabular}{llllll}
\hline \multicolumn{1}{c}{ Cultivars } & \multicolumn{1}{c}{ SS } & \multicolumn{1}{c}{ TA } & SS/TA & Vit C & TC \\
\hline Cristal & $12.66 \mathrm{a}$ & $0.47 \mathrm{~b}$ & $26.95 \mathrm{a}$ & $10.24 \mathrm{c}$ & $0.22 \mathrm{c}$ \\
Cristal Tacoari & $12.42 \mathrm{a}$ & $0.99 \mathrm{a}$ & $12.76 \mathrm{~b}$ & $18.65 \mathrm{a}$ & $0.27 \mathrm{~b}$ \\
Colibri & $12.27 \mathrm{a}$ & $0.41 \mathrm{~b}$ & $30.60 \mathrm{a}$ & $13.43 \mathrm{~b}$ & $0.14 \mathrm{~d}$ \\
Delicioso Precoce & $9.46 \mathrm{a}$ & $0.36 \mathrm{c}$ & $27.20 \mathrm{a}$ & $13.99 \mathrm{~b}$ & $0.09 \mathrm{~d}$ \\
Jóia 1 & $9.12 \mathrm{~d}$ & $0.38 \mathrm{c}$ & $24.92 \mathrm{a}$ & $13.36 \mathrm{~b}$ & $0.10 \mathrm{~d}$ \\
Jóia 2 & $11.09 \mathrm{~b}$ & $0.44 \mathrm{~b}$ & $26.22 \mathrm{a}$ & $18.14 \mathrm{a}$ & $0.20 \mathrm{c}$ \\
Jóia 4 & $8.47 \mathrm{~d}$ & $0.33 \mathrm{c}$ & $25.98 \mathrm{a}$ & $14.42 \mathrm{~b}$ & $0.12 \mathrm{~d}$ \\
Marli & $9.54 \mathrm{c}$ & $0.35 \mathrm{c}$ & $27.87 \mathrm{a}$ & $10.12 \mathrm{c}$ & $0.11 \mathrm{~d}$ \\
Okinawa & $10.99 \mathrm{~b}$ & $0.99 \mathrm{a}$ & $11.23 \mathrm{~b}$ & $18.44 \mathrm{a}$ & $0.30 \mathrm{~b}$ \\
Pérola de Itaquera & $11.35 \mathrm{~b}$ & $0.38 \mathrm{c}$ & $30.47 \mathrm{a}$ & $9.08 \mathrm{c}$ & $0.21 \mathrm{c}$ \\
Premier & $9.75 \mathrm{c}$ & $0.36 \mathrm{c}$ & $27.90 \mathrm{a}$ & $15.77 \mathrm{a}$ & $0.06 \mathrm{~d}$ \\
Tropical & $10.11 \mathrm{c}$ & $0.34 \mathrm{C}$ & $30.57 \mathrm{a}$ & $19.24 \mathrm{a}$ & $0.46 \mathrm{a}$ \\
\hline Means followed by the same letter in the columns are not significantly different at 5\% probability by the Scott-Knott test. Ss ('Brix); TA (\%); Vit C (mg ascorbic acid per 100g
\end{tabular}

of flesh); and TC (mg.100 $\mathrm{g}^{-1}$ flesh).

The carotenoids content ranged from

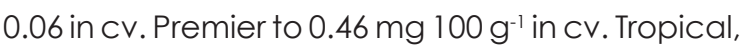
higher values when compared to the contentes observed by Segantini et al. (2012) in peaches produced in San Manuel - SP that ranged between 0.04 and $0.07 \mathrm{mg} 100 \mathrm{~g}^{-1}$. Segantini et al. (2012) observed the carotenoid content of 0.04 mg $100 \mathrm{~g}^{-1}$ in fruits of $\mathrm{cv}$. Marli, while in this study, we observed $0.11 \mathrm{mg} 100 \mathrm{~g}^{-1}$ for the same cultivar. This result reinforces the potential of of Zona da Mata region for the production of good quality peaches, since carotenoids have an important role in human nutrition as a source of vitamin $A$ and for their antioxidant activity that is associated with a decrease in the risk of degenerative diseases (Veronezi \& George, 2011).

The cultivars Delicioso Precoce and Marli presented the, higher fruit mass and diameter.

Cultivars Jóia 2 and Tropical had highest transport resistance and longest shelf life, due to its firmer flesh.
The cultivar 'Tropical' stood out in relation to quality attributes, showing the best balance between acidity and soluble solids and highest contents of vitamin C and carotenoids.

\section{Acknowledgements}

The authors thank to CNPq, CAPES and FAPEMIG for the financial support.

\section{References}

Albuquerque, A.S., Bruckner, C.H., Cruz, C.D., Salomão, L.C.C. 2000. Avaliação de cultivares de pêssego e nectarina em Araponga, Minas Gerais. Revista Ceres 47:401-410.

Alexandre, H.V., Figueirêdo, R.M.F. de, Queiroz, A.J. de M., Oliveira, E.N.A. de. 2014. Armazenamento de pitanga em pó. Comunicata Scientiae 5: 8391.

Chitarra, M.I.F. Chitarra, A.B. 2005. Pós-colheita de frutas e hortaliças: fisiologia e manuseio. 2.ed. rev. e ampl. UFLA, Lavras, Brasil. 785p.

Cruz, C.D. 2006. Programa genes-versão windows-Aplicativo computacional em 
genética estatística (Versão 2007). UFV, Viçosa, Brazil.

FAO. Food and Agricultural Organization. Faostat. Disponível em: <http://faostat3.fao.org>. Acesso em 14 jul. 2015.

IBGE - Instituto Brasileiro de Geografia e Estatística. Produção Agrícola Municipal. 2013. Disponível em: <http://www.sidra.ibge.gov.br> Acesso em 24 jul. 2015.

Leonel, S., Pierozzi, C.G., Tecchio, M.A. (2011). Produção e qualidade dos frutos de pessegueiro e nectarineira em clima subtropical do estado de São Paulo. Revista Brasileira de Fruticultura 33: 118-128.

Lichtenthaler, H.K. 1987. Chlorophylls and carotenoids: Pigments of photosynthetic biomembranes. Methods in Enzymology 148: 349382.

MDIC (Sistema AliceWeb) - Sistema de análise das informações de comércio exterior via internet do ministério do desenvolvimento, indústria e comércio exterior. Disponivel em: <http:// aliceweb.desenvolvimento.gov.br>. Acesso em 20 jul. 2015.

Montevecchi, G., Vasile Simone, G., Masino, F., Bignami, C., Antonelli, A. (2012). Physical and chemical characterization of Pescabivona, a Sicilian white flesh peach cultivar [Prunus persica (L.) Batsch]. Food Research International 45: 123131.

SILVA, D.F.P., Silva, J.O.C., Matias, R.G.P., Ribeiro, M.R.R., Bruckner, C.H. 2013 Correlação entre características quantitativas e qualitativas de frutos de pessegueiros na geração F2 cultivados em região subtropical. Revista Ceres 60: 053-058.

Ramos, D.P. Leonel, S. 2008. Características dos frutos de cultivares de pessegueiros e de nectarineira, com potencial de cultivo em Botucatu, SP. Bioscience Journal 24: 10-18.

Reig, G., Alegre, S., Gatius, F., Iglesias, I. (2015). Adaptability of peach cultivars [Prunus persica (L.) Batsch] to the climatic conditions of the Ebro Valley, with special focus on fruit quality. Scientia Horticulturae 190: 149-160.

Segantini, D.M., Leonel, S., Lima, G.P.P., Costa, S.M. Ramos, A.M.R.P. 2012. Caracterização da polpa de pêssegos produzidos em são ManuelSP. Ciência Rural 42: 52-57.

Souza, A.V., Kohatsu, D.S., Lima, G.P.P.E., Vieites, R.L. (2009). Conservação pós-colheita de pêssego com o uso da refrigeração e da irradiação. Revista Brasileira de Fruticultura 31: 1184-1189.
Toralles, R.T., Vendruscolo, J.L., Malgarim, B.M., Cantilhano, R.F., Schunemann, A.P.P. Antunes, P.L. 2008. Características físicas e químicas de cultivares brasileiras de pêssegos em duas safras. Revista Brasileira de Agrociência 14: 327-338.

Veronezi, C.M., Jorge, N. 2011 . Carotenóides em abóboras. Boletim do Centro de Pesquisa de Processamento de Alimentos 29: 9-20.

Wagner Júnior, A., Bruckner, C.H., Salomão, L.C.C., Pimentel, L.D., Silva, J.O.C., Santos, C.E.M. (2009). Avaliação da necessidade de frio de pessegueiros por meio de ramos enxertados. Revista Brasileira de Fruticultura 31: 1054-1059.

Wagner Júnior, A., Bruckner, C.H., Cantín, M.C., Sánchez, M.A.M., Santos, C.E.M. 2011 . Seleção de progênies e genitores de pessegueiro com base nas características dos frutos. Revista Brasileira de Fruticultura 33: 170-179. 